\title{
The New Frontier In Sustainable DEVELOPMENT: WORLD SUMMIT ON SUSTAINABLE DEVELOPMENT TYPE II PARTNERSHIPS
}

\author{
Marion Wilson*
}

This article examines an innovative form of environmental governance that was introduced at the World Summit on Sustainable Development in Johannesburg in 2002. The "Type II" partnership is a voluntary, multi-stakeholder initiative to achieve sustainable development outcomes. Little has been written on why partnerships have gained prominence in the international environmental arena, and whether they are deserving of this. This article argues that Type II partnerships are a promising solution to sustainable development issues. Despite criticism, the emphasis placed on Type II Partnerships at the World Summit was deserved. The article also explores ways partnerships may be utilised as an effective mechanism for achieving sustainable development. The process surrounding the World Summit on Sustainable Development partnerships, and the guidelines for those partnerships, can be refined to improve their effectiveness. This article highlights issues that influence improvement of partnerships. A number of principles to guide changes made to the partnership process are formulated, and suggestions are made on how partnerships can become as effective as possible.

\section{INTRODUCTION}

This Summit will be remembered not for the treaties, the commitments, or the declarations it produced, but for the first stirrings of a new way of governing the global commons - the beginnings of a shift from the stiff formal waltz of traditional diplomacy to the jazzier dance of improvisational solution-oriented partnerships that may include non-government organizations, willing governments and other stakeholders.

Jonathan Lash, President, World Resources Institute ${ }^{1}$

* Submitted as part of the LLB(Hons) programme at Victoria University of Wellington. 
The World Summit on Sustainable Development (WSSD), held in Johannesburg in 2002, was notable for a new instrument taking centre stage as the primary method of achieving sustainable development. The Type II Partnership was in many practical respects an alternative to international law. The partnership was seen as a way of taking action on sustainable development issues, rather than addressing these issues through treaties or agreements. Partnerships are not new, but the WSSD gave unprecedented emphasis to this type of voluntary initiative. Yet many questions remain about the efficacy of partnerships and their role in international environmental governance.

This article addresses two central questions: (i) do partnerships deserve the position of prominence in the field of international environmental governance that they have attained as a result of the WSSD, and (ii) how can partnerships best be made effective to achieve sustainable development goals?

Part II introduces Type II Partnerships, exploring their features, their purpose, and why they became a feature of the WSSD, as well as examining the progress made on partnerships generally and in three case studies. The article raises the issue of whether partnerships should have such a prominent role in global environmental governance for the sustainable development agenda, looking at the potential weaknesses and benefits of partnerships, in Part III. In Part IV the article highlights factors that shape the improvements that need to be made: development theory, legitimacy and corporate accountability. From these analyses a number of principles are formulated which are used in Part V to shape suggested improvements to partnerships.

\section{TYPE II PARTNERSHIPS}

\section{A Origin of Type II Partnerships}

1 The World Summit on Sustainable Development 2002

The United Nations (UN) intended the WSSD to "reinvigorate the global commitment to sustainable development." 2 Preceding the Summit, it was clear that progress on sustainable development in the last decade had been unsatisfactory. The UN General Assembly emphasised the need for action and results. ${ }^{3}$ Twenty-two thousand people from over 191 states gathered as part of the largest international conference ever held. ${ }^{4}$

1 World Resources Institute "The Johannesburg Summit" (2002) < http://www.wri.org> (last accessed 26 July 2005)

2 UNGA Resolution 199 (20 December 2000) A/RES/55/199 para 1.

3 UNGA Resolution 199, above n 2.

4 World Summit on Sustainable Development $2002<$ http://www.johannesburgsummit.org $>$ (last accessed 26 July 2005). 
The major outcomes of the WSSD included the Johannesburg Declaration on Sustainable Development, and the Plan of Implementation. ${ }^{5}$ Notwithstanding a few encouraging substantive commitments, for instance on biodiversity and safe water, Johannesburg was for many a forum for disappointment and lost opportunities. The conference revealed political stalemates on a number of significant issues.

However, the most remarkable feature of the Summit was the emergence of voluntary, multistakeholder partnerships as an official WSSD outcome. Type II Partnerships are controversial and much criticised. Yet they offer a measure of hope to an international system that has struggled to make progress in achieving sustainable development goals. Much of the success of the WSSD rests on the success of partnerships as a tool for achieving progress on sustainable development.

\section{Type I versus Type II outcomes}

During the negotiation process leading up to the WSSD it became clear that two types of outcomes were to be promoted at Johannesburg. "Type I" referred to documents or agreements that are negotiated by states, including political agreements like conventions and declarations. The Chairman of the Third WSSD Preparatory Conference (PrepCom 3) in his Opening Statement described the Type II outcomes as "a series of commitments and action-oriented coalitions focused on deliverables [that] would contribute in translating political commitments into action."6 Type II outcomes are commitments and targets made by individual or groups of governments along with other interested parties or "stakeholders". ${ }^{7}$ These voluntary partnerships allow a number of stakeholders to contribute to agreements aimed at furthering sustainable development.

Type II Partnerships have been touted as the solution to the "crisis in implementation" in the sustainable development agenda. ${ }^{8}$ Approximately 220 partnerships were announced at the WSSD, with a promised US\$235 million in resources. ${ }^{9}$

5 In the Johannesburg Declaration states recommitted themselves to action to bring about sustainable development, The Johannesburg Declaration on Sustainable Development (4 September 2002) A/CONF199/L6/Rev2; The Plan of Implementation details priorities for action, Draft Plan of Implementation of the World Summit on Sustainable Development (4 September 2002) A/CONF199/L1.

6 Third World Summit on Sustainable Development Preparatory Committee "Explanatory note by the Chairman of the Preparatory Committee" (March 2002) < http://www.johannesburgsummit.org/ html/documents/prepcom3.html $>$ (last accessed 26 July 2005).

7 Global Legislators' Organisation for a Balanced Environment "Partnerships and the WSSD" (submission to Second World Summit on Sustainable Development Preparatory Conference, Namibia, 2002) 3.

8 Sustainable Development Issues Network "Taking Issue: Questioning Partnerships" (Issue Paper No 1, 2002) $1-2$

9 World Summit on Sustainable Development 2002 "Key Outcomes of the Summit" (20 September 2002) http://www.johannesburgsummit.org/> (last accessed 2 August 2005). 


\section{Features of Type II partnerships}

A number of features of these Type II Partnerships were discussed at PrepCom 3 in April 2002. The partnership initiatives are not intended as a substitute for Type I commitments by governments. These remain central to national, regional, and global efforts to pursue sustainable development. ${ }^{10}$ Type I and II initiatives are interlinked. The partnerships are voluntary and self-organising in nature.

Partnerships involve a number of actors. State governments often take a lead role, but intergovernmental organisations and non-governmental organisations (NGOs) are also leading partners. UN bodies, academic institutions and private sector organisations are also key actors in Type II Partnerships. Partnerships can operate at global, regional, sub-regional or national level. There is a vast range of possible areas of focus. The subject matter of partnerships is hugely diverse. $^{11}$

Type II Partnerships are not an invention of the Johannesburg Summit. Similar mechanisms have been used in the development field over a number of years. Companies, civil society groups, local authorities, and others have formed numerous development and environment partnerships over many years. ${ }^{12}$ However, the Type II Partnership mechanism adopted at Johannesburg and subsequently defined has a distinctive character. This arises from the prominent position the partnerships have been given, and from the parameters defined for them. WSSD partnerships are different because of the linkage between these initiatives and defined sustainable development objectives. ${ }^{13}$ To have WSSD status, partnerships must be registered with the Commission on Sustainable Development (CSD).

\section{CSD Guidelines for partnerships}

Registration of partnerships with the CSD is voluntary, but once this is done a series of guidelines outlined in the CSD-11 Decision on Partnerships must be taken into account. The CSD Guidelines provide that partnerships are: ${ }^{14}$

10 World Summit on Sustainable Development $2002<$ http://www.johannesburgsummit.org $>$ (last accessed 26 July 2005).

11 The range of subject matter of partnerships includes deserts, climate change, forests, mining, coral reefs, HIV/AIDS, tourism, tropical diseases and clean air: United Nations Division for Sustainable Development Database $<$ http://webapps01.un.org/dsd/partnerships $>$ (last accessed 26 July 2005).

12 Sashcha Muller-Kraenner "Partnerships as an Instrument to Implement the Johannesburg Policy Targets" in Jan Martin Witte, Charlotte Streck and Thorsten Benner (eds) Progress or Peril? Partnerships and Networks in Global Environmental Governance: The Post Johannesburg Agenda (Global Public Policy Institute, Washington DC, 2003) 55, 56.

13 Muller-Kraenner, above n 12, 56.

14 UN Commission on Sustainable Development "Report on the eleventh session" (9 May 2003) E/CN17/2003/6 para 22 . 
- voluntary initiatives by governments and stakeholders;

- contributing to the implementation of Agenda 21, the Programme for Further Implementation of Agenda 21 and the Johannesburg Plan of Implementation;

- not a substitute for but a supplement to commitments by governments;

- $\quad$ new and add value to existing implementation processes;

- in accord with economic, social and environmental dimensions of sustainable development in their design and implementation;

- $\quad$ based on predictable and sustained resources;

- $\quad$ sectorally and geographically balanced;

- transparent and accountable, allowing exchange of information with governments and other stakeholders;

- $\quad$ publicly announced; and

- consistent with national laws and sustainable development strategies.

The partnerships must provide information within their CSD registration on how each of these guidelines is met. $^{15}$

Partnerships are essentially self-governing. Partnerships in existence at the time of the Summit, such as the Global Alliance for Vaccines and Immunization (GAVI), were given as examples of successful partnership structures. ${ }^{16}$

GAVI is a non-WSSD public-private partnership to increase children's access to vaccines in developing States. It brings together developing and industrialised governments, vaccine manufacturers, NGOs, research institutes, UNICEF, the World Health Organisation (WHO), the Bill and Melinda Gates Foundation and the World Bank, each of which has a specific role. ${ }^{17}$ GAVI has a comprehensive, multi-levelled structure, including the Board, Executive Committee, Working Group and Secretariat. ${ }^{18}$

15 The reports of all the WSSD partnerships are registered with the CSD and available on the United Nations Division for Sustainable Development Database, above n 11.

16 World Summit on Sustainable Development $2002<$ http://www.johannesburgsummit.org $>$ (last accessed 26 July 2005).

17 Global Alliance for Vaccines and Immunization (GAVI) $<\mathrm{http}: / /$ www.vaccinealliance.org $>$ (last accessed 26 July 2005).

18 Global Alliance for Vaccines and Immunization, above n 17 


\section{What are partnerships trying to achieve?}

The raison d'être of partnerships is to implement sustainable development. Sustainable development is commonly defined as "development that meets the needs of the present without compromising the ability of future generations to meet their own needs", ${ }^{19}$ and has been endorsed by the global community as a central principle in a number of fundamental legal instruments. ${ }^{20}$ Sustainable development is about reaching a compromise between the often conflicting goals of development and environmental protection. ${ }^{21}$

While there are concerns about sustainable development, ${ }^{22}$ it makes sense to build on the existing framework. The sustainable development framework is internationally accepted and draws together the environment with heavily interconnected social and economic issues. ${ }^{23}$ An area of the framework requiring attention is the development of strategies and programmes for implementation.

To be effective as instruments implementing sustainable development, partnerships will need to balance the goals of economic and social development with that of environmental protection. Through the requirement that CSD partnerships must implement Agenda 21, the Johannesburg Plan of Implementation, and the Programme for the Further Implementation of Agenda 21, ${ }^{24}$ partnerships are intrinsically related to the broad goal of sustainable development, which plays a large part in each of these documents.

\section{Why did partnerships become a feature of the WSSD?}

A number of rationales can be posited for the prominence given to Type II Partnerships at the WSSD. First, it is argued that partnerships will provide more effective, results-oriented implementation of sustainable development aims than has currently been possible. Type I agreements have not been successful in bringing about sustainable development. The evident advantages of partnership arrangements made them an attractive alternative at the Summit.

19 World Commission on Environment and Development Our Common Future (Oxford University Press, Oxford, 1987) 43.

20 Mary Pat Williams Silveira "International Legal Instruments and Sustainable Development: Principles, Requirements and Restructuring" (1995) 31 Willamette L Rev 239, 241.

21 Patricia Birnie and Alan Boyle International Law and the Environment (2 ed, Oxford University Press, New York, 2002) 44.

22 John C Dernbach "Targets, Timetables and Effective Implementing Mechanisms: Necessary Building Blocks for Sustainable Development" (2002) 27 Wm \& Mary Envtl L \& Pol'y Rev 79, 80.

23 Dernbach, above n 22, 81 .

24 United Nations Commission on Sustainable Development "Partnerships for Sustainable Development: Report of the Secretary-General" (10 February 2004) E/CN17/2004/16, 3. 
A second reason for the prominent role of partnerships is that prior to the WSSD it became clear that the Summit was unlikely to produce any new conventions. Organisers despaired at the likely success of conventional methods of agreement-seeking diplomacy. ${ }^{25}$ PrepCom 4 revealed a decided lack of political will among States to agree on targets and timetables to address pressing environmental and social problems, such as fishing, climate change and loss of biodiversity, at the Summit. ${ }^{26}$ The United States especially appeared to have no confidence in a convention approach and is likely to have heavily influenced other governments. Within the current political climate there is a general degree of hostility towards governments making commitments through international agreements. $^{27}$

An additional explanation for the emphasis on partnerships at the WSSD is that they are instruments well suited to the current international system. Changes in recent decades have resulted in a proliferation of international actors. Power today is shared not only by the approximately 190 states and the international institutions they have created, but also by private entities, multinational corporations and NGOs. ${ }^{28}$ The multi-sectoral approach of partnerships inherently engages a wide range of actors and makes use of the increasing interconnection that has come from globalisation.

\section{B Progress Made Since Johannesburg}

Since the WSSD partnerships were launched at the Summit in 2002, progress has been made both institutionally and in the development and implementation of partnerships. While only three years have passed since Johannesburg some trends and concerns are evident in the developments that are occurring.

First, developments have occurred in the organisation of the WSSD partnership process. The CSD has made detailed information on current partnerships accessible to all interested parties through a database. ${ }^{29}$ This development encourages the involvement of other parties in existing

25 Liliana B Andonova and Marc A Levy "Franchising Global Governance: Making Sense of the Johannesburg Type II Partnerships" In Olav Schram Stokke and Øystein B Thommessen (eds) Yearbook of International Cooperation on Environment and Development 2003/2004 (Earthscan, London, 2004) 19, 22.

26 Corporate Europe Observatory "Countdown to Rio +10: 'Sustainable Development' and the Public-Private Pantomime" (August 2002) Corporate Europe Observer Amsterdam.

27 Tammy W Klein "Type II Partnerships in the Transport Context: Fulfilling Our Promises, Making the Dream a Reality?" (2003) 15 Geo Int'l Envtl L Rev 531, 533.

28 Charlotte $\mathrm{Ku}$ "Global Governance and the Changing Face of International Law" (2001 John W Holmes Memorial Lecture) in ACUNS Reports and Papers No 2 (Academic Council on the United Nations System, New Haven, 2001) 29.

29 United Nations Commission on Sustainable Development "Partnerships for Sustainable Development: Report of the Secretary-General", above n 24; United Nations Division for Sustainable Development Database, above n 11. 
partnerships, as well as raising the profile of partnerships generally, thereby encouraging further partnership initiatives.

Partnerships Fairs have been held at CSD-11 and CSD-12 as venues for hearing progress on existing WSSD partnerships, and also as an opportunity for various groups to network and develop new partnerships. ${ }^{30}$

These developments indicate that some progress has been made in increasing dialogue and information sharing on partnerships.

Secondly, there have been some interesting practical developments in the last three years. ${ }^{31}$ As of September 2004, there are 292 partnerships registered with the CSD. ${ }^{32}$

More than half of the CSD-registered partnerships are global in scale. There are 58 regional, 72 sub-regional and ten national scale partnerships. Most of the regional initiatives focus on the AsiaPacific region and Africa. ${ }^{33}$ The duration of partnerships varies based on the nature of objectives and targets. One quarter of registered partnerships examined in the report are open-ended, while the average duration of finite partnerships is 4.8 years. ${ }^{34}$

According to the Secretary-General's Report, the number of partners in the registered partnerships examined varies from three to 93. Eighty-five per cent of partnerships include the involvement of a government, while two thirds have UN or other intergovernmental organisation involvement. ${ }^{35}$ Hale notes that private sector involvement is limited. Some private sector

30 UN Commission on Sustainable Development "CSD-11 Partnerships Fair-Report" (8 May 2003).

31 The WSSD partnerships have been examined in several studies. This article draws on information from three: Tom Hale Managing the Disaggregation of Development: How the Johannesburg "Type II" Partnerships Can Be Made Effective (Woodrow Wilson School of Public and International Affairs, Princeton, 2003); Andonova and Levy, above n 25; and the United Nations Commission on Sustainable Development "Partnerships for Sustainable Development: Report of the Secretary-General", above n 24; as well as from empirical research based on the United Nations Division for Sustainable Development Database, above n 11 .

32 United Nations Division for Sustainable Development Database, above n 11, there are currently also 27 activities to initiate partnerships registered with the secretariat.

33 United Nations Division for Sustainable Development Database, above n 11, there are 26 partnerships in the Asia-Pacific region and 23 in the African region.

34 United Nations Commission on Sustainable Development "Partnerships for Sustainable Development: Report of the Secretary-General", above n 24.

35 United Nations Commission on Sustainable Development "Partnerships for Sustainable Development: Report of the Secretary-General", above n 24, 8. 
corporations are involved. ${ }^{36}$ However, private sector companies lead less than 2 per cent of the total. $^{37}$

The majority of partnerships are driven by traditionally powerful donor states and their own aims, rather than by states with a demand for specific sustainable development improvements. Andonova and Levy compared states' level of participation in partnerships with their environmental performance scores as assigned by the Yale/Columbia Environment Sustainability Index (ESI). There is not a consistent correlation between low ESI scores and levels of participation. ${ }^{38}$ The states most in need of sustainable development initiatives are not the group most involved in partnerships. A few states account for the majority of government participation in partnerships. ${ }^{39}$ Hale argues that this indicates a serious concern with the breadth of involvement in partnerships. ${ }^{40}$

Generally, because of their multi-sectoral nature, partnerships tend to cut across several themes. A wide range of themes are covered by the partnerships analysed in the Secretary-General's Report. However some themes are under-represented. ${ }^{41}$ Forty-six per cent of the partnerships specifically target an environmental issue. Common themes are energy, oceans, agriculture, water and biodiversity. ${ }^{42}$ The majority are designed to develop "means of implementation" such as capacity building, education, and financial and trade mechanisms for sustainable development. ${ }^{43}$

As of February 2004, 65 per cent of registered partnerships had submitted updates on their progress. The Secretary-General's Report indicated that the majority of partnerships are still involved in an organisational phase. ${ }^{44}$ Only a few had progressed into co-ordination and

36 See for example, Global Initiative on Transport Emissions <http://www.un.org/esa/gite $>$ (last accessed 26 July 2005) for instance, a number of automotive and fuel companies, such as Ford Motor Company, ExxonMobil and BP, are involved in the Cleaner Fuels and Vehicles Partnership.

37 Hale, above $\mathrm{n} 31,10$. Of the 292 partnerships currently registered with the CSD, only 39 involve a private sector partner

38 Andonova and Levy, above n 25, 26.

39 United Nations Division for Sustainable Development Database, above n 11. Indonesia, the United States, France, Australia, Italy and Japan together account for 70 per cent of the partnerships led by governments.

40 Hale, above n 31, 10-11.

41 These include biotechnology, chemicals, desertification, drought, marine resources, mining and mountains United Nations Commission on Sustainable Development "Partnerships for Sustainable Development: Report of the Secretary-General", above n 24.

42 United Nations Division for Sustainable Development Database, above n 11.

43 Andonova and Levy, above n 25, 25

44 The organisational phase involving fundraising, outreaching to potential new partners, and development of internal governance mechanisms and implementation strategy: United Nations Commission on Sustainable Development " Partnerships for Sustainable Development: Report of the Secretary-General", above n 24, 11. 
implementation phases, and many of those had initiated the partnerships prior to the WSSD. The clear indication is that the organisational phase of partnerships takes a significant amount of time. ${ }^{45}$

Most partnerships also lack adequate monitoring and evaluation mechanisms. Ivanova's investigations found that monitoring and assessment in most partnerships was perfunctory at best or even absent. She found only two that referred specifically to external review systems. The vast majority only refer to internal monitoring and evaluation of the Steering Committee. ${ }^{46}$

Twenty-eight of the 292 partnerships contain some reference to contributing to the implementation of a multilateral environmental treaty in their CSD-registered description. The Framework Convention on Climate Change (FCCC) ${ }^{47}$ and the Convention on Biological Diversity $(\mathrm{CBD})^{48}$ are the two treaties that are most commonly referred to in partnerships. Three more partnerships aim to contribute to the implementation of international law generally. ${ }^{49}$

\section{Case Studies}

\section{Asia Forest Partnership}

The Asia Forest Partnership (AFP), promoting sustainable forest management in Asia, was launched at the Johannesburg Summit. ${ }^{50}$ The Partnership, lead by Japan, Indonesia, the Nature Conservancy, and the Centre for International Forest Research (an NGO), aims to address five urgent issues: governance and law enforcement, capacity-building, illegal logging, forest fires, and rehabilitation and reforestation. ${ }^{51}$ The partners meet as the partnership's foremost decision-making body. The leading partners have made stronger commitments to facilitate and coordinate the activities of the partnership, but do not have more authority or rights than other partners. ${ }^{52}$

45 United Nations Commission on Sustainable Development "Partnerships for Sustainable Development: Report of the Secretary-General", above n 24, 11.

46 Maria Ivanova "Partnerships, International Organizations, and Global Environmental Governance" in Witte, Streck and Benner, above n 12, 9 and 22. The two partnerships which referred to external review systems were the Great Apes Survival Partnership and the International Coral Reef Action Network, both led by UNEP.

47 United Nations Framework Convention on Climate Change (9 May 1992) 1771 UNTS 107; (1992) 31 ILM 849 .

48 United Nations Convention on Biological Diversity (5 June 1992) 1760 UNTS 79; (1992) 31 ILM 818.

49 These are the Environmental Law Capacity Building Programme for Sustainable Development, International Law for Sustainable Development and Local Capacities for Global Agendas.

50 United Nations Division for Sustainable Development Database, above n 11.

51 Asia Forest Partnership Website <http://www.asiaforests.org > (last accessed 26 July2005).

52 United Nations Division for Sustainable Development Database, above n 11. 
The AFP is an interesting example of a Type II Partnership that meets the WSSD guidelines. AFP aims to increase coordination and reduce duplication of existing initiatives. The partnership is able to identify areas where new programs are needed. ${ }^{53}$ The AFP attempts to harmonise existing initiatives, and develop new standards and laws for the region. The partnership aims to contribute to Chapter 11 of Agenda 21 relating to the protection and sustainable development of forests. ${ }^{54}$

\section{Pacific Islands Adaptation Initiative}

The New Zealand Government, through NZAID, is involved in the Pacific Islands Adaptation Initiative. This partnership has the overall goal to "catalyse action and strengthen partnerships at all levels to enable the Pacific Islands' region to understand and respond to climate change, climate variability and sea level rise." ${ }^{55}$ The initiative is lead by the South Pacific Regional Environmental Programme (SPREP). The initiative's objectives are to coordinate adaptation activities, support enabling activities to meet UNFCCC obligations, to mainstream climate change and adaptation into national and regional planning, and to mobilise resources. ${ }^{56}$

The Adaptation Initiative is yet to be finally developed. NZAID is currently waiting on other partners to initiate action. ${ }^{57}$

3 Cooperative Initiative on Invasive Alien Species

New Zealand agencies play a major role in the Cooperative Initiative on Invasive Alien Species (IAS) led by the World Conservation Union (IUCN) and established prior to the WSSD. ${ }^{58}$ IAS are a major factor responsible for decline in world biodiversity. ${ }^{59}$ Islands are particularly vulnerable to IAS and can suffer huge loss in biodiversity. ${ }^{60}$ The IUCN facilitates and coordinates the initiative. This partnership aims to facilitate cooperation in management of IAS on the Pacific Islands. The

53 United Nations Division for Sustainable Development Database, above n 11.

54 United Nations Division for Sustainable Development Database, above n 11.

55 United Nations Division for Sustainable Development Database, above n 11.

56 United Nations Division for Sustainable Development Database, above n 11.

57 Interview with Roger Cornforth, NZAID, Ministry of Foreign Affairs and Trade (the author, Wellington, 9 August 2004).

58 United Nations Division for Sustainable Development Database, above n 11.

59 The World Conservation Union Invasive Species Specialist Group, Cooperative Initiative on Invasive Alien Species on Islands <http://www.issg.org/islandIAS.html > (last accessed 26 July 2005).

60 The World Conservation Union Invasive Species Specialist Group, above n 59. 
initiative focuses on threats posed by IAS to island biological diversity and builds on work already occurring. Its mission is threefold: prevention, eradication and control. ${ }^{61}$

The initiative's specific targets include implementing existing international instruments, including the CBD and International Plant Protection Convention. The partnership will produce annual plans of work to provide direction and transparency. However, the initiative's targets also include being flexible and responsive to needs identified by island communities. ${ }^{62}$ The partnership also requires a large degree of creativity. The initiative puts effort into determining how to practically implement strategies. For instance, the partnership is currently working on an innovative attempt to eradicate cane toads from Fijian islands. ${ }^{63}$

The Cooperative Initiative on Invasive Alien Species partnership has direct links with the CBD. The March 2001 CBD Plenary Meeting formally endorsed the partnership. ${ }^{64}$ It recognised the urgent need to deal with IAS in isolated and vulnerable ecosystems. This partnership is an example of one which has aims that correlate to aspects of a treaty regime. There is opportunity here for much greater involvement of the treaty body in the partnership.

The partnership brings together governments of the South Pacific with donor governments and experts, such as those from New Zealand's Department of Conservation and Auckland University. ${ }^{65}$

\section{SHOULD PARTNERSHIPS HAVE SUCH AN IMPORTANT ROLE?}

This section examines the concerns and potential benefits of partnerships, and assesses whether they can make a valuable contribution to sustainable development.

\section{A Concerns About Type II Partnerships}

Type II Partnerships have met with a mixed reaction since they were launched in Johannesburg. While a majority of governments, and international organisations and much of the private sector welcomed the move toward partnerships, it was met by fierce opposition from many NGOs. ${ }^{66}$ Many groups highlighted concerns about partnerships that they believe will hinder progress towards

61 Interview with Alan Saunders, Coordinator, Cooperative Island Initiative (the author, Wellington, 22 September 2004).

62 United Nations Division for Sustainable Development Database, above n 11.

63 Interview with Alan Saunders, above n 61.

64 United Nations Convention on Biological Diversity "Subsidiary Body on Scientific, Technical and Technological Advice 6 Recommendation" VI/4, para 18.

65 United Nations Division for Sustainable Development Database, above n 11.

66 Jan Martin Witte and Charlotte Streck "Introduction: Progress or Peril? Partnerships and Networks in Global Environmental Governance" in Witte, Streck and Benner, above n 12, 1, 3. 
sustainable development. This section identifies the central concerns about Type II Partnerships and analyses their validity.

\section{Do not create legally enforceable obligations}

As an informal, non-binding mechanism, partnerships do not create enforceable obligations. Unlike international treaties, they place no legal obligation on states or any other actor. Consequently, partnerships are not enforceable in a legally binding way.

It is similarly argued that Type II Partnerships dilute state responsibility. For instance, the Johannesburg Plan of Implementation contains a commitment to introduce cleaner fuels and vehicles, and eliminate lead from gasoline. ${ }^{67}$ There is no framework for the implementation of this commitment except through the voluntary, non-binding Global Partnership for Cleaner Fuels and Vehicles. ${ }^{68}$ While much has been said about the lack of enforcement powers in multilateral environmental treaties, to an even greater extent partnerships have no "teeth". ${ }^{69}$

While this is a valid concern regarding the WSSD partnership process, the alternative, legally enforceable mechanisms like treaties, can also be problematic. Treaties can be slow to negotiate and nations can be reluctant to tie themselves to the specificity often involved. ${ }^{70}$ Just because an instrument creates legal obligations does not mean that it will be enforced or complied with.

\section{Detract from Type I agreements}

A central concern about Type II Partnerships is that they will draw governments' focus away from Type I agreements, such as multilateral environmental treaties. They may also distract media and public scrutiny from failures to achieve governmental agreements. ${ }^{71}$ The changed emphasis is likely to further reduce the establishment, compliance, and enforcement of international environmental law.

NGOs have protested that partnerships are not only a distraction but an excuse for states looking to avoid environmental and development obligations. Greenpeace is concerned that Type II outcomes are being promoted to avoid Type I outcomes. The United States and other state governments insisted prior to the WSSD that the agenda contain no new multilateral goals,

67 Draft Plan of Implementation of the World Summit on Sustainable Development, above n 5, para 49.

68 Klein, above n 27, 548.

69 Carl Pope, "Alone in the World: Bush ends an era of environmental treaties" (January/February 2003) Sierra San Francisco.

70 Geoffrey Palmer "New Ways to Make International Environmental Law" (1992) 86 Am J Int'l L 259, 269.

71 George Pring "The 2002 Johannesburg World Summit on Sustainable Development: International Environmental Law Collides with Reality, Turning Jo'burg into Joke'burg" (2002) 30 Denv J Int'l L \& Pol'y 410,415 . 
international environmental treaties, binding agreements, fixed targets, or timetables. ${ }^{72}$ Greenpeace argues that the United States promoted Type II agreements to avoid the commitments inherent in Type I agreements. European governments were also criticised for putting too much emphasis on partnerships. ${ }^{73}$ In particular critics condemned the emphasis on Type II outcomes as a blatant attempt to divert attention from developed states' reluctance to reduce trade subsidies and commit further resources for developing countries. ${ }^{74}$ The outcomes of the Summit add weight to these arguments. The Political Declaration, and Plan of Implementation impose very few new obligations on states. $^{75}$

This is a legitimate concern. Few solid commitments were made at Johannesburg and many environmental regimes are struggling with compliance and enforcement problems. However, not all governments view partnerships as a distraction and excuse. ${ }^{76}$ The potential to draw governments' attention away from international agreements is also not an inherent feature of Type II Partnerships, but rather a political response of governments. If the partnership mechanism is developed effectively, this response could potentially be avoided. At the WSSD and post-Johannesburg CSD meetings, it has been emphasised that partnerships must supplement not substitute for international agreements. ${ }^{77}$ With careful planning and structuring, many of these difficulties may be avoided.

72 Pring, above $\mathrm{n} 71,413$.

73 Rémi Parmentier, Political Director, Greenpeace International "Type 1 Versus Type 2 Outcomes: Explaining the Jargon, Exposing the Trap" (Conference on Sustainable Development: Can the Johannesburg Summit Save the World and Can We Save the Summit?, Brussels, 8 May 2002).

74 Rachel L Swarns "US Shows Off Aid Projects at UN Development Meeting" (30 August 2002) New York Times New York A6.

75 It was originally intended that the Plan of Implementation would contain targets and timetables to realise sustainable development. After prolonged negotiations, including near collapse at the final preparatory meeting in Bali, a much less detailed final text was reached. It does contain over 30 targets, though many of these are restatements of existing Millennium Development Goals. See Tom Bigg "The World Summit on Sustainable Development: Was it Worthwhile?" (International Institute of the Environment and Development, London, 2003); World Summit on Sustainable Development "Johannesburg Plan of Implementation" (4 September 2002) A/CONF199/L1.

76 For instance the New Zealand government has supported the partnership process. NZAID has allocated $\$ 1.6$ million in new funding for partnerships, with further funding envisaged in coming years. Ministry of Foreign Affairs and Trade $<$ http://www.mfat.govt.nz $>$ (last accessed 26 July 2005).

77 See for example UN Commission on Sustainable Development "Report on the eleventh session", above $\mathrm{n}$ 14. 


\section{Lack of accountability}

A major problem that has been raised is the lack of accountability structures within Type II Partnerships. Partnerships should report biennially to the CSD. ${ }^{78}$ However there is no mechanism in place for ensuring that these programmes follow their stated objectives and do promote sustainable development. This is especially concerning as corporate actors, notorious for their lack of accountability, are involved. ${ }^{79}$ NGOs such as the Sustainable Development Issues Network claim that the regulation and monitoring of corporations in Type II Partnerships is essential, as corporate malfeasance scandals such as Enron and Arthur-Anderson illustrate. ${ }^{80}$

There is a growing civil society consensus on the need for binding international rules for transnational corporations. A European watch group believes the voluntary involvement of corporations in partnerships will undermine efforts to impose binding rules. ${ }^{81}$

Without the transparency that accountability provides, transnational corporations can use partnerships to improve their environmental image, or "greenwash", without putting much of their rhetoric into practice. In the absence of any accountability guidelines, partnerships give corporations an opportunity to continue with business, but protect themselves from criticism because they appear to have the UN's approval. ${ }^{82}$

Involvement in WSSD partnerships will improve the image of corporations, yet this improvement may not be well founded. The Corporate Europe Observer states that "by institutionalising their role as "stakeholder" in official fora, corporations gain considerable influence in any outcomes and benefit from an image boost as they are seen to be part of the solution." 83

This is indeed a genuine concern relating to partnerships. The emphasis placed on Type II Partnerships as the primary instrument for implementing sustainable development warrants an assurance that partners in these initiatives will at least work in good faith towards their goals and will not undermine sustainable development efforts. The actors in partnerships need to be held accountable for partnerships to be effective. This problem is not insurmountable. Partnerships provide a chance to create a structure for that accountability. Sustainable development will be more

78 See for example UN Commission on Sustainable Development "Report on the eleventh session", above n 14.

79 Douglas Litowitz "Are Corporations Evil?" (2004) 58 U Miami L Rev 811, 811.

80 Sustainable Development Issues Network, above n 8.

81 Corporate Europe Observatory, above n 26.

82 Pring, above n 71, 416.

83 Corporate Europe Observatory, above n 26. 
achievable if corporate actors are working within the WSSD process rather than acting completely independently of it and being subject to no accountability guidelines.

\section{Conflicts of interest}

Another concerning aspect of Type II Partnerships is that they bring together actors with divergent agendas in one initiative. The different stakeholders may pull the partnership in opposite directions rendering it ineffective. Conversely, stronger parties may dominate.

Ideally the multi-stakeholder model should bring together different actors to reach a consensus on outcomes so that they are more easily implemented. However, in reality unequal power relations between different stakeholders must be taken into account. ${ }^{84}$ As the participants of the Asia-Pacific People's Forum on Sustainable Development observed: "This concept of partnerships and stakeholders perpetuates the myth that there is a collective endeavour, that all players are equal and conflicts of interest can be resolved by roundtables seeking consensus." 85 Many NGOs are clearly committed to environmental objectives. However, corporations place greater emphasis on economic growth and the multilateral trading system as solutions to sustainable development issues. ${ }^{86}$

The Corporate Europe Observer argues that the private sector involvement in partnerships is dangerous. Effectively this is "leaving the basic needs of billions of poor to market forces." ${ }^{\text {}} 7$ The same can be argued for the state of the environment. Corporations are profit-driven. Economic interests can easily override human and environmental interests in decision-making. In current competitive markets those who avoid their social and environmental responsibilities are often rewarded. ${ }^{88}$ A partnership that is heavily influenced by economic interests could have its sustainable development aims severely undermined.

The potential for conflicts of interests among partners in WSSD partnership initiatives is a glaring concern. However, this is a concern that can be overcome. In the current international system, it is essential to involve multiple stakeholders in sustainable development management. It is possible for the WSSD partnerships to address this concern.

84 Corporate Europe Observatory, above n 26.

85 Statement of the Asia-Pacific People's Forum on Sustainable Development (25 November 2001, Phnom Penh) available at $<$ http://www.johannesburgsummit.org $>$ (last accessed 26 July 2005).

86 International Chamber of Commerce "Sustainable Development: A Vision for Partnership" (Statement by ICC Commission on Environment and Energy, Paris, 2002).

87 Corporate Europe Observatory, above n 26.

88 EcoEquity Coalition "Critical Considerations about Type II Partnerships" (EcoEquity Coalition, 2002) iii. 


\section{Previous uncoordinated aid projects}

Partnerships have been seen as replicating the "former, failed system of uncoordinated 'foreign aid' projects." 89 Developed countries arguably impose their projects on developing countries. This results in a lack of ownership of the development initiatives for the people directly affected by those actions. The WSSD partnerships are arguably donor-driven aid projects renamed and repackaged. Much of the funding allocated to partnerships is argued to be not new, but reassigned from existing aid budgets. ${ }^{90}$ A related concern is that partnerships may develop in a similar way to foreign aid projects and result in fragmented, uncoordinated initiatives. ${ }^{91}$

While this is a concern, it is not an intrinsic problem of partnerships. The degree to which partnerships are donor-driven and not adding value depends on the approach of states. The WSSD partnerships do in fact provide some important differences. Because of the multi-stakeholder approach, there is the potential for the involvement of a group of states, including developing states, in determining how to utilise. There is also potential for additional funding, particularly from the private sector. The CSD Guidelines do attempt to overcome this concern. The CSD-11 decision stated that: "partnerships should have concrete value addition to the implementation process and should be new - that is not merely reflect existing arrangements." 92 If this rule can be guaranteed with greater accountability, then this concern will be alleviated.

\section{B Strengths of Partnerships}

Partnerships have much to offer the international arena in sustainable development management. Partnerships, if utilised in the correct way, provide an opportunity to make significant progress towards sustainable development. Because the WSSD partnership mechanism is as yet in its infancy, many of the benefits identified remain speculative.

\section{Practical action towards implementation}

While international environmental law provides goals and standards for achieving environmental improvement, it usually does not outline practical steps for implementation. Partnerships, on the other hand, are centrally about implementation. Swift and direct action on the ground can get around bureaucratic red tape and result in meaningful changes. ${ }^{93}$ The

89 Pring, above n 71, 415.

90 Julia Steets "Accountability, Ignored by Partnerships at Own Peril" (Global Public Policy Institute, Berlin, 2004).

91 EcoEquity Coalition, above n 88.

92 UN Commission on Sustainable Development, "Report on the eleventh session" above n 14.

93 Carl Bruch and John Pendergrass "Symposium: The Road From Johannesburg: Type II Partnerships, International Law and the Commons" (2003) 15 Geo Int'l Envtl L Rev 855, 865. 
implementation of sustainable development is also a complex process, requiring a range of specific actions from many actors. These actions vary between regions, states and localities. ${ }^{94}$ The nature of partnerships means that they can be used to identify and implement specific actions that are tailored for each situation. International law is not this flexible.

Partnerships, therefore, fill a gap in international sustainable development governance where there is an undeniable need. Partnerships make implementation a priority.

However, this benefit relies on the partnerships being "value added", as is required by the CSD Guidelines. ${ }^{95}$ Partnerships must enhance rather than just rename existing projects and they must involve additional funding in order to be effective.

\section{Addressing problems otherwise not addressed}

Partnerships can tackle problems which are not adequately addressed by other means. Whereas international agreements often take a general or global focus, partnerships can be targeted to the specific issues. The Sustainable Energy for Sustainable Development in the Caribbean initiative, for example, is a regional partnership to reduce dependence on petroleum and demonstrate the viability of renewable energy sources. ${ }^{96}$ Partnerships are also effective at addressing problems that an individual actor cannot address alone. For example, a sustainable development campaign involving a government, a private sector organisation, and a network of NGOs will be more effective than one run by any of these bodies alone. ${ }^{97}$

If partnerships are implemented in a thorough and targeted way, this can be an important benefit. The scale of some sustainable development problems may be too small to be dealt with under an international agreement. An issue may not be given enough priority among a group of states to result in action. However, among a group of motivated stakeholders there may be enough impetus to make a difference. Coordinated international action can be taken through partnerships, where otherwise this type of action simply would not occur.

\section{Improved quality and effectiveness}

Partnerships can improve the quality and effectiveness of environment solutions. Partnerships pool together a wide range of knowledge, perspectives and capabilities through their collaborative

94 Royal Institute of International Affairs What Will it Take to Make 'Type 2' Partnerships For Implementation Work? (Discussion Paper, Royal Institute of International Affairs, London, 2002).

95 United Nations Commission on Sustainable Development, "Report of the eleventh session", above n 14.

96 United Nations Division for Sustainable Development Database, above n 11.

97 Minu Hemmati and Roger Whitfield "Sustainable Development Partnerships In the Follow-up to Johannesburg: Suggestions for Effective Mechanisms at the Regional and International Level" (Stakeholder Forum for Our Common Future, London, 2003) 4. 
process. ${ }^{98}$ Partnerships provide an opportunity to acknowledge specific conditions and needs requiring targeted measures. ${ }^{99}$ Ideally these factors mean that partnerships can deliver improved strategies for implementation. Optimists also argue that "pooling public and private resources in synergetic relationships could improve the overall problem solving capacity". ${ }^{100}$

It is likely that the sustained effort at producing partnership initiatives through the WSSD process will increase the quality of strategies and programmes produced, particularly as more experience is gained over time. A well-coordinated UN-driven partnerships programme is more likely to produce effective results for sustainable development than the uncoordinated pre-WSSD environment. The improvements in quality and effectiveness of strategies and programmes through partnerships will depend on there being a high degree of shared information and experiences.

\section{Going beyond international agreements}

Partnerships provide an opportunity for a group of actors to work towards environmental goals that go beyond internationally agreed targets. The partnership mechanism allows goal-setting and coordinated action among groups willing to do more than what the often-constrained international community can achieve. ${ }^{101}$ For instance, the Asia Forest Partnership establishes stronger and more defined commitments towards sustainable forest management than have been agreed to in any international agreement. ${ }^{102}$ If a group of states and other parties are willing to commit to certain standards and targets in environmental protection, this norm creation and standard setting may influence states and groups outside the partnerships and in the long term make it easier to reach international agreement. ${ }^{103}$

This benefit, though potentially very valuable, is purely speculative at this stage. It is likely that engaging interested parties in dialogue and action on certain environmental issues will generate momentum for greater state commitments.

98 Hemmati and Whitfield, above n 97, 4.

99 Stakeholder Forum for Our Common Future "Comments on the proposed framework of outcomes documents for Earth Summit 2002" (Stakeholder Forum for Our Common Future, London, 2002) 2.

100 Klaus Dieter Wolf "Private Actors and Legitimacy of Governance Beyond the State" (Paper presented to "Governance and Democratic Legitimacy" European Consortium on Political Research Joint Sessions, Grenoble, 6-11 April 2001) 2.

101 Hemmati and Whitfield, above n 97, 4

102 United Nations Division for Sustainable Development Database, above n 11.

103 Hemmati and Whitfield, above n 97, 4. 


\section{Wider participation}

Through the WSSD partnerships, a significant number of groups and organisations have become involved in implementing sustainable development programmes. The nearly 300 registered partnerships involve over 1000 actors. ${ }^{104}$ This is significant, as a "participation gap" has been identified in global politics, where some actors have little or no decision-making ability. ${ }^{105}$ The involvement of more actors is likely to make the implementation of sustainable development objectives more effective. Partnerships have the potential to empower stakeholders to make a difference in environmental protection. Participation is, by nature, active and creative, allowing previously inaccessible human and other resources to be harnessed. ${ }^{106}$ The range of actors in the GAVI partnership is an example of this. ${ }^{107}$

This is a highly significant potential benefit of partnerships. Participation is central to implementing sustainable development. This aspect of partnerships will be discussed in further detail below. ${ }^{108}$

\section{Additional resources}

Partnerships are a vehicle for governments, international agencies and the private sector to channel further resources into sustainable development efforts. Many NGOs have repeatedly stressed the need for states and organisations to make real commitments to the Johannesburg Plan of Implementation and Millennium Development Goals by making additional resources available, not to merely re-channel existing resources. ${ }^{109}$ Because partnerships incorporate a thorough analysis of the actions needed to deliver sustainable development, they can potentially be used in making the case for additional funding for sustainable development. Partnerships may involve private sector actors willing to invest resources who would otherwise not be involved. ${ }^{110}$

Funding is a key to the success of sustainable development initiatives. Any mechanism that can generate more funding has the potential to be very valuable. By involving more actors, partnerships open the door to increased funding, particularly from the private sector. Through raising the priority of particular sustainable development issues, partnerships may also attract more funding to areas of

104 Hemmati and Whitfield, above n 97, 4

105 Andonova and Levy, above n 25, 20.

106 Hemmati and Whitfield, above n 97, 4.

107 Global Alliance for Vaccines and Immunization, above n 17.

108 See Part V C Participatory and Locally-Oriented Approach.

109 Hemmati and Whitfield, above n 97, 4.

110 Royal Institute of International Affairs, above n 94. 
need. However, many who hoped that cooperation with the private sector would attract new resources are disappointed to see that often funds are drawn from existing projects. ${ }^{11}$

\section{Conclusion: The Value of Partnerships}

Despite the controversy surrounding the WSSD partnership process and a number of purported concerns, partnerships can be a valuable tool and should be pursued. A number of the concerns about partnerships identified above are valid, yet not insurmountable. The potential benefits of partnerships outweigh the concerns, particularly as many of the concerns can be overcome through careful management.

Since the Summit, a greater emphasis has been placed on the pragmatic considerations regarding the best strategies for getting partnerships to work. NGOs appear to be raising fewer objections to partnerships as a concept. Many have the attitude that they should make the most of the accepted framework. The majority of NGOs were never fundamentally opposed to partnerships. Many were already working in partnership with businesses and governments. NGO concerns are now centred on how partnerships are being handled under the WSSD system. ${ }^{112}$

The remainder of this article examines how the WSSD partnerships can best be utilised to make progress on sustainable development.

\section{THEORETICAL AND PRACTICAL CONSIDERATIONS INFORMING THE DEVELOPMENT OF A PARTNERSHIPS FRAMEWORK}

\section{A Development Theory}

This section provides an overview of changes in development theory and particularly the development of alternative perspectives. These provide valuable insights into how partnerships should ideally function.

In the 1980s the international community faced a serious crisis in development with significant parts of the world experiencing dehumanising poverty, the collapse of ecological systems and deeply strained social structures. ${ }^{113}$ Environmental deterioration was contributing to hunger, violence and exploitation through problems such as poor soil fertility, deforestation and overfishing. ${ }^{114}$

111 Steets, above n 90

112 Witte and Streck, above n 66, 4

113 David C Korten Getting to the $21^{\text {st }}$ Century: Voluntary Action and the Global Agenda (Kumarian Press, Connecticut, 1990) 1.

114 Korten, above n 113, 2. 
At this time many development theorists began rethinking the traditional economic growth development paradigm which emphasised the accumulation of capital as the driving engine of growth. ${ }^{115}$ Economic growth was believed to result in a trickle-down of wealth to the poorest in society. However, the emphasis on economic growth resulted in extravagant consumption of the world's resources by a select few. Two major flaws have been identified: the majority of benefits go to those least in need, and growth patterns reduce the ability of the global ecology to support output levels. ${ }^{116}$ These flaws led many theorists to reconceptualise development.

Brohman notes that perhaps, more than any other factor, it is the increasing environmental damage that is responsible for this rethink of development. ${ }^{117}$

Many current theories of development have a more holistic focus. The "alternative development" perspective, for example, redefined the goals of development. It rejected economic growth as an end in itself, focusing on social inequality and poverty. ${ }^{118}$

Perspectives like these can contribute greatly to our understanding of partnerships providing several important features required for successful development programmes.

Development must primarily address local needs. Sustainable development programmes must attempt to address the problems facing those most in need of assistance. Brohman argues that environmental problems contain an important locality-based element and therefore require solutions that are sensitive to local social and ecological conditions. Designing a project that fits its environmental context involves assessing resources, possibilities, and political, social and economic constraints, ${ }^{119}$ and accounting for local variations in class, gender, ethnic and other social structures. ${ }^{120}$

New Zealand's approach in the Pacific reflects these concerns. Attention is paid to the introduction of sustainable development at a community as well as national level. For instance, customary land ownership needs to be considered, as this has more practical significance than national land regulation. ${ }^{121}$

115 Catherine Gwin and Joan M Nelson Perspectives on Aid and Development (John Hopkins University Press, Washington DC, 1997) 3.

116 Korten, above n 113, 3.

117 John Brohman Popular Development: Rethinking the Theory and Practice of Development (Blackwell, Oxford, 1997) 307.

118 John Martinussen Society, State and Market: A Guide to Competing Theories of Development (Zed Books, London, 1997) 291.

119 C Bryant and L White Managing Development in the Third World (Westview Press, Boulder, 1982) 109.

120 Brohamn, above n 117, 335 .

121 Interview with Roger Cornforth, above n 57. 
Development should recognise the need for local participation. Local participation allows local ownership of development initiatives. Overseas development aid has often been problematic. Development work has been professionalised in most Third World states under exclusionary Western frameworks. ${ }^{122}$ Decisions have too often been imposed by outsiders who are not locally accountable. ${ }^{123}$

Enhancing local participation allows access to an accumulated wealth of practical knowledge at a local level that can enhance future development programmes. Local familiarity with development initiatives produces more appropriate methods and expectations. ${ }^{124}$ Successful local organisations can act as vehicles for coordinating and spreading the benefits of outside assistance. ${ }^{125}$

Achieving a truly people-centred development requires a substantial decentralisation of decision-making processes. Control should be given to those affected by decisions, rather than to officials who bear little of the consequences of their actions themselves. ${ }^{126}$

The WSSD partnership mechanism fits well within a holistic, local-focused development approach. Brohman argues that the popular movement must find ways to scale up its influence on development strategies. ${ }^{127} \mathrm{He}$ calls for international institutions to create new methods for popular organisations and groups to exchange information and be mutually supportive. ${ }^{128}$ Partnerships within the WSSD process can be a method of achieving just this.

One of the reasons NZAID is supportive of the concept of partnerships is that they will achieve greater donee input into development programmes and their management. They hope to see greater "donor-harmonisation" through partnerships, where partners get together and "sing the same song", but in ways that are designed by the developing states. ${ }^{129}$

Development theory and practice suggests that partnerships need to be locally-focussed and to place emphasis on local participation.

122 Brohman, above n 117, 328.

123 Brohman, above n 117, 336 .

124 Brohman, above n 117, 326.

125 G Honadle and J Van Sant Implementation for Sustainability: Lessons from Integrated Rural Development (Kumarian Press, West Hartford, 1985) 47.

126 D Korten and R Klauss People Centered Development: Contrbutions Toward Theory and Planning Framework (Kumarian Press, West Hartford, 1984) 301.

127 Brohman, above n 117, 345-346.

128 Brohman, above n 117, 350 .

129 Interview with Roger Cornforth, above n 57. 


\section{B Legitimacy}

One aspect of the WSSD partnership process which it is important to analyse is its legitimacy. As a process involving parties at an international level making decisions on concrete action for sustainable development, the legitimacy of WSSD partnerships may influence their effectiveness. If there is widespread adherence to the WSSD process with the majority of sustainable development initiatives being combined under one framework, it is likely to be more effective. ${ }^{130}$ Bodansky defines legitimacy as the "quality that leads people to accept authority - independent of coercion, self-interest or rational persuasion - because of the general sense that the authority is justified."131

Bodansky argues that authority can be legitimated by its origin or source. ${ }^{132}$ In the partnership framework the UN, an international organisation of high standing, is responsible. It is based on the consent of states, which enhances its legitimacy. Franck explores the idea of symbolic validation as a factor determining legitimacy. He argues that symbols, ritual, and pedigree convey authority. ${ }^{133}$ The UN has its own flag. It contains multiple organisations, with their own officials and symbols. ${ }^{134}$ These factors contribute to the UN's authority and, through this, the legitimacy of the WSSD partnerships.

Another of Bodansky's bases for legitimacy is the involvement of fair procedure in decisionmaking. ${ }^{135}$ The decision to accept an initiative as a WSSD partnership and the guidelines regulating partnerships are made by the 53 members of the CSD. Their decisions have yet to be challenged in any significant way. However, more time is needed to see whether this factor plays a role in the legitimacy of WSSD partnerships. In the future, any successful outcomes of partnerships may also contribute to their legitimacy. ${ }^{136}$

130 Legitimacy has been analysed by several academics in relation to its effect on international environmental convention regimes. While there is a marked difference between such rule-establishing regimes and the partnership process, legitimacy can affect their effectiveness in similar ways. See Daniel Bodansky "The Legitimacy of International Governance: A Coming Challenge for International Environmental Law?" (1999) 93 Am J Int'l L 596; Thomas M Franck "Legitimacy in the International System" (1988) 82 Am J Int'l L 705.

131 Bodansky, above n 130, 601.

132 Bodansky, above n 130, 612.

133 Franck, above n 130, 725.

134 Franck, above n 130, 731.

135 Bodansky, above n 130, 612.

136 Bodansky, above n 130, 612. Bodansky's third basis of legitimacy is the success of the authority in producing the desired outcomes. The years that have passed since the Johannesburg Summit have not yet provided enough time to draw conclusions on the success of partnerships. 
Bodansky also argues that public participation influences the legitimacy of an authority "by giving stakeholders a sense of ownership in the process." 137 Transparency and access to information contribute to the ability of people to participate. These elements are central to partnerships. Partnerships attempt to involve a range of stakeholders.

The contribution of experts is another factor Bodansky sees as contributing to the legitimacy of an authority. ${ }^{138}$ Partnerships provide a greater opportunity for expert involvement in sustainable development decision-making. Many academic and scientific organisations are involved as partners in partnership initiatives. This factor is also limited, however. Environmental decision-making involves questions of value as well as fact. ${ }^{139} \mathrm{It}$ is rarely straightforward to determine the best solution to an environmental problem. There is also a great potential for uncertainty in scientific data. Yet experts can contribute to partnerships, especially where there is no significant disagreement over values. It will be important to ensure that all partners, including experts, have the opportunity to contribute equally to the partnership's decision-making.

It has been argued that the UN may risk conferring legitimacy on initiatives without adequate transparency for ensuring that these initiatives are acting in accordance with sustainable development objectives. ${ }^{140}$ The UN gives source-based legitimacy, yet the results may undermine this. To ensure that the partnership process deserves its UN-affiliated status, better clarification of guidelines and structures, including greater accountability and transparency, is needed. ${ }^{141}$

The WSSD partnership mechanism will be more successful if it is perceived as legitimate. This discussion indicates that the process needs to ensure public participation, expert participation, and transparency and accountability to maintain and enhance its legitimacy.

\section{Corporate Accountability}

Corporate accountability was a major issue at the WSSD. A lack of accountability in partnerships generally or among certain partners can undermine their effectiveness and legitimacy. These concerns need to be addressed if the Type II outcomes are to be successful.

137 Bodansky, above n 130, 617.

138 Bodansky, above n 130, 612

139 Bodansky, above n 130, 620 .

140 Pring, above n 71, 416.

141 Steets, above n 90. 
A number of NGOs have argued that sustainable development and environmental degradation cannot be effectively addressed without meaningful commitments to corporate accountability. ${ }^{142}$

Over the past decades there have been changes in the international system relating to the role of transnational corporations (TNCs). TNCs have come to dominate the global economy. ${ }^{143}$ As a result of these changes, there is an increasing distance between corporate leadership and the citizens and communities for whom they provide essential services. This distance creates difficulties when communities seek redress when problems arise. ${ }^{144}$ Weak governance in many developing countries compounds the problem. TNCs are often operating within states with weaker environmental and social standards than their "home" states, and also possibly where corruption is endemic. These conditions increase the risk that the activities of TNCs will lead to negative environmental and social impacts. ${ }^{145}$ For instance, in Ecuador TNCs involved in oil extraction have poisoned ecosystems, endangering the welfare of indigenous people who are dependent on those ecosystems. ${ }^{146}$ The rush to developing countries to seek cheaper labour and materials is often called the "race to the bottom". It can result in the exploitation of impoverished people and the abuse of the environment. Yet for the corporation it means more profits. ${ }^{147}$

Another factor contributing to the growing concern about corporate accountability is that the private sector is playing a greater role in delivering sustainable development objectives. ${ }^{148}$ Type II Partnerships are a significant example of this. Partnerships allow the private sector to actively engage in sustainable development projects. For instance, BP and Shell Petroleum are involved in

142 Daniel Graymore and Isabella D Bunn "A World Summit for Business Development?" (Christian Aid, London, 2002); Friends of the Earth International "Towards Binding Corporate Accountability" (Draft position paper for PrepCom 2, Friends of the Earth International, Amsterdam, 2002).

143 Lauren A Mowery "Earth Rights, Human Rights: Can International Environmental Human Rights Affect Corporate Accountability?" (2002) 13 Fordham Envtl Law J 343, 343. Many corporations have economies that rival those of many developing countries, see Frank René López "Corporate Social Responsibility in a Global Economy After September 11: Profits, Freedom, and Human Rights" (2004) 55 Mercer L Rev 739 , 740 .

144 Friends of the Earth International, above n 142

145 Fanny Calder and Malaika Culverwell "Following up the World Summit on Sustainable Development Commitments on Corporate Social Responsibility" (Interim Report, Royal Institute on International Affairs, London, 2004) 11.

146 Mowery, above n 143, 343.

147 López, above n 143, 740.

148 Calder and Culverwell, above n 145, 12. For instance, between 1990 and 2001, the private sector was responsible for 2,500 infrastructure projects in developing countries with investments totalling \$US750,000: World Bank "Private Sector Infrastructure: A Review of Projects with Private Sector Participation, 19002001" (World Bank, Washington DC, 2002) 1. 
the Global Gas Flaring Reduction Partnership, and ExxonMobil and agribusiness Syngenta are involved in the NetMark Plus partnership for malaria prevention. ${ }^{149}$

NGOs, such as Friends of the Earth International, are concerned that businesses may have inappropriate power within partnerships. ${ }^{150}$ Corporations' emphasis on economic interests may conflict with environmental aims. This could limit the ability of partnerships to provide environmentally sound solutions. A lack of corporate accountability may enable TNCs to "greenwash". While on one hand they are contributing to sustainable development projects, on the other they are carrying out actions that heavily compromise the environment.

The WSSD partnerships system needs to take account of these potential problems by addressing them in the way partnerships are structured and regulated.

\section{IMPROVING PARTNERSHIPS: PRINCIPLES AND SUGGESTIONS}

From analysis of the strengths and weaknesses of partnerships, the progress being made and issues of concern within this, and discussions of development theory and legitimacy, it has been possible to determine a set of six central principles. These need to guide solutions for partnerships if they are to become an effective and legitimate part of global sustainable development governance. A number of suggestions aimed at overcoming the serious shortcomings in the current WSSD partnership framework are presented under each principle.

\section{A Promoting and Supplementing International Environmental Law}

As discussed previously, it is important to ensure that Type II Partnerships do not detract from Type I agreements. Dernbach argues that specific internationally agreed goals are necessary for achieving sustainable development. Targets and timetables can identify priorities, force decisionmakers to clarify objectives, and demonstrate commitment thus giving greater credibility. ${ }^{151}$ For instance, Agenda 21 provides a framework which other initiatives can be measured against and gives the concept of sustainable development substance. ${ }^{152}$ Partnerships are likely to be most effective when they are working towards internationally agreed goals. Treaties that focus on a particular environmental problem or region can provide these overall goals.

Partnerships can have an important role in enhancing international environmental law. Measures need to be taken to ensure there is as much coordination as possible with Type I

149 United Nations Division for Sustainable Development Database, above n 11.

150 Calder and Culverwell, above n 145, 18.

151 Dernbach, above n 22, 89-90.

152 Dernbach, above n 22, 103. 
agreements. A clear framework is needed as a bridge between the more general Type I commitments and the detailed, concrete work of partnerships. ${ }^{153}$

\section{Partnerships' objectives linked to conventions}

Where a partnership has a similar subject matter to a treaty regime, the partnership could aim to implement the treaty obligations in its objectives. This is currently occurring in a number of the WSSD partnerships. ${ }^{154}$ Partnerships will assist states in fulfilling their obligations, rather than taking unrelated action to deal with the same problems. There is potential for much more of this type of linkage.

In the Asia Forest Partnership's report to the CSD, they state that they contribute to the Convention on Biological Diversity, the UNFCCC and the UN Forum on Forests proposals and plan of action. ${ }^{155}$ AFP's contribution to the implementation of international law and policy appears to be inadvertent, but valuable. However, if the partnership involved more explicit contributions to these conventions and organisations, they may benefit from support and coordination from convention institutions. The AFP would also be improved by more explicit guidelines on the role of each of its partners.

Simply stating the linkage between a partnership and international agreements is perhaps too vague. There is no method of ensuring action will occur or influencing the type of action. Other options which link Type I and Type II outcomes more closely may be more effective.

\section{Involvement of treaty bodies in partnerships}

Institutions of international environmental convention regimes could play a hands-on role in partnerships. Where a partnership has been established with a purpose that includes implementing an environmental treaty, the treaty's institutions are, more than most other actors, a "stakeholder" in the activities planned. Secretariats could become involved in partnerships. They could share resources and relevant information. Treaty regimes could influence the actions taken by partnerships. Secretariats could even become partners with members of secretariats or other institutions attending meetings. By having this direct level of interaction both the partnership and the convention regime benefit. The expertise and resources available to secretariats and other treaty institutions would be valuable and relevant to the voluntary initiative. The sharing of resources is

153 Global Legislators' Organisation for a Balanced Environment, above n 7, 3.

154 The partnership for the Enhancement of Regional Strategy on Climate Change through the Asia-Pacific Network on Climate Change is an example. This partnership is led by Japan and involves 23 other states. The partnership aims to implement the UN Framework Convention on Climate Change and the Kyoto Protocol through policy dialogues among States, exchange of information and experiences, capacity building, and information gathering. See United Nations Division for Sustainable Development Database, above $n 11$.

155 United Nations Division for Sustainable Development Database, above n 11. 
efficient. The regime institution is actively involved in implementing its obligations. This suggestion does involve some additional costs however.

Regimes that become involved in partnerships will have to maintain their general focus, rather than committing too many resources to a specific project. The cost, time and resources allocated to partnerships must be balanced against forwarding the overall purposes of the treaty. The involvement of secretariats of treaty regimes in partnerships may require a redefinition of their role. However, this is needed if Type I and Type II are to properly supplement each other.

\section{Establishment of partnerships in treaty process}

The obligations found in international environmental conventions could include requirements that states facilitate the formation of partnerships or become involved in existing partnerships to implement those treaty obligations. This would provide a direct link between Type I and Type II initiatives. The partnership would be based on a legally binding obligation on states to make sure that it happens. Partnerships provide a method of ensuring a degree of implementation. Such an inclusion would be concrete action in the quest to implement the treaty.

This would require states to take their convention obligations seriously, and commit funding and resources to seeing implementation take place. Partnerships can assist with capacity-building where states struggle for this reason to implement conventions. Partnerships also provide the opportunity for flexibility in achieving convention implementation.

This suggestion does involve some risks. The treaty bodies may need to review state involvement in particular partnerships to ensure they are worthwhile projects, and in accord with the treaty's purposes.

\section{Partnerships working towards Type I agreements}

Partnerships endeavouring to address an environmental issue not subject to an international environmental regime could strive to create an environmental treaty. The partnership process involves consultation and negotiation, which may be conducive to reaching agreement on obligations. State involvement in partnerships could lead to common positions on environmental issues being established.

\section{Conclusion}

There is great potential for more direct relationships between treaty bodies and partnerships. These direct approaches link obligations to implementation initiatives, thereby filling current gaps in international environmental governance.

Throughout the analysis of Type II Partnerships it was clear that states need to retain the leadership position in international environmental governance and take seriously their international environmental obligations. Partnerships should not be seen as a way for states to fulfil their environmental commitments without Type I commitments also being made. 


\section{B High Standards of Transparency and Accountability}

Corporate accountability is an important issue to resolve if partnerships are to be effective. Accountability and transparency are also vital to maintain the legitimacy of the WSSD partnership process.

Stakeholders are likely to approach their tasks with more urgency and use more effective methods if they are held accountable for progress made. Monitoring and evaluation mechanisms would increase the transparency of partnerships and allow assessment of whether they are actually contributing to sustainable development. ${ }^{156}$

\section{Monitoring and transparency}

To achieve greater transparency there must be improved monitoring systems. This can be achieved through ongoing communication between the partnerships and an overarching organisation. A self-reporting system is likely to be the most realistic way of achieving this. Clear guidelines on how to carry out the reporting are required. ${ }^{157}$ Reporting requirements should include providing information on how these guidelines are being fulfilled and what progress is being made.

Public access to information on partnerships should be required in guidelines. Establishing a website is an effective method for the partnership to do this. Otherwise making the partnership's reports publicly available through the central organisation may provide the desired transparency. It is especially important to make information available on how funding is being spent.

\section{Follow-up}

After adequate time has been given to allow the partnership to start properly implementing its objectives, a "robust, credible follow-up process" should be utilised. ${ }^{158}$ Partnerships need to be held accountable for keeping to the WSSD guidelines and to their own objectives. This will require ongoing dialogue between partnerships and an overarching organisation. This organisation will be responsible for identifying partnerships that are not fulfilling their objectives through analysis of reports and investigations initiated by the organisation. Support, perhaps in the form of expertise, information and assistance in finding funding, should be provided where this would be useful. However, where partnerships consistently do not meet guidelines or make any progress, firm action needs to be taken to ensure the high standards, and therefore legitimacy, of the process. These

156 For the opposite point of view see Björn Stigson "A Business Perspective on Partnerships" in Witte, Streck and Benner (eds), above n 12, 43 and 45. President of the World Business Council for Sustainable Development Björn Stigson argues that the value in partnerships is in bringing together actors who believe they can achieve results by themselves and do not need an external body to monitor their actions.

157 Royal Institute of International Affairs, above n 94.

158 Royal Institute of International Affairs, above n 94. 
partnerships could lose WSSD accreditation and the benefits of being linked in with the partnership process.

\section{Corporate accountability}

A corporate accountability convention has been suggested as a method of ensuring the private sector is held accountable for its actions throughout the world. ${ }^{159}$ However, this is unlikely to eventuate in the near future because of the reluctance of corporations to be bound in this way and the pressure they can exert on states.

Non-binding corporate accountability agreements are therefore a more realistic option. Corporate accountability requirements, to which private sector partners must agree, should be written into the partnership guidelines. This could require private sector partners to be open about all their activities that have a potential environmental impact. Within the WSSD partnerships framework, "naming and shaming" tactics can be used to impact markets where corporations are failing to live up to standards. On the other hand, corporations with exemplary records and involvement in partnerships should be heralded as examples.

\section{Participatory and Locally-Oriented Approach}

In accordance with development theory, partnerships need to prioritise wide participation, particularly of local communities and those most affected by initiatives, if they are to be effective. The present donor-driven emphasis needs to be replaced with initiatives driven by the communities and states suffering most from sustainable development problems. The overall WSSD partnership structure needs to continue to allow a broad range of activities that are suitable to individual localities. High levels of participation will increase the legitimacy of the process.

\section{Achieving this approach}

Consultation with the people directly affected by the proposed sustainable development initiatives should be a partnership guideline.

NZAID's approach in the Pacific provides a commendable model. NZAID has left the initiation of partnerships to Pacific regional organisations, such as the South Pacific Regional Environment Programme. ${ }^{160}$ The organisations found the common needs by analysing national assessments. Partnerships were developed around these needs. Local development of programmes and local involvement in these is central to NZAID's philosophy of partnership involvement. ${ }^{161}$

159 Friends of the Earth International, above n 142.

160 NZAID <http://www.nzaid.govt.nz> (last accessed 26 July 2005).

161 NZAID, above n 160. Partnerships have been formally established in four initiatives. These are the AsiaPacific Leadership Forum HIV/AIDS initiative, the Invasive Species on Islands initiative, the Governance for Community-Based Sustainable Development initiative and the Pacific Partnership on Sustainable Water 
An important corollary is that partnerships should build on existing local strategies and programmes. NZAID's Pacific umbrella initiatives did not involve the imposition of foreign programmes simply to create something new for the sake of the WSSD. They also built on existing regional strategies. ${ }^{162}$ Similarly the Cooperative Initiative on Invasive Alien Species based its activities on previous work done by SPREP and continues to work with Pacific agencies. ${ }^{163}$

\section{Stakeholder Capacity-Building Through Learning and Information Sharing}

If the Type II Partnership process is to be most effective, it needs to include mechanisms for exchange of information and learning between partnerships. Stakeholders need to learn from the successes and failures of other partnerships. This can occur in a more intentional and effective manner. Those involved in partnerships should be able to receive training on partnership management and practice. Different partnership efforts on similar themes should be able to connect to learn from one another.

\section{Consultation and cluster groups}

Linkages can be created between partnerships through consultation and cluster groups. These groups of partnerships, related by similar themes or geographic areas, can share experiences and coordinate their efforts.

\section{Publicity}

It is important to publicise successful and unsuccessful methods to encourage improvement of partnerships. A central organisation should present this information in a way that is accessible to all those involved in partnerships. This could be done through creating summary progress reports that highlight successes and failures.

\section{Training}

The WSSD partnership framework should provide teaching and training on aspects of partnership management and development practice. For instance, those involved in partnerships could be trained in how to attract and efficiently use funding.

\section{E Clarification of Roles and Relationships of Partners}

In order to limit the effects of conflicts of interest between partners on the effectiveness of partnerships, there needs to be greater regulation or guidance on the roles of partners. Where a

Management. Eight Pacific umbrella initiatives are being explored as WSSD partnerships. These initiatives include Adaptation, Energy, Vulnerability, Education, Traditional Knowledge and Genetic Resources and Waste Management.

162 Interview with Roger Cornforth, above n 57.

163 Interview with Alan Saunders, above n 61. 
conflict of interests could occur there needs to be mechanism for resolving this. Partnerships are likely to be more effective if partners are aware of their roles and responsibilities.

\section{Neutral facilitators}

Facilitators can be involved in establishing partnerships. They can have a role in inviting different stakeholders to take part. They can put an emphasis on involving corporate partners, as currently there are fewer corporations involved in partnerships than is desired. ${ }^{164}$ Neutral facilitators could organise meetings of these parties to establish dialogue between them and could assist in the design of partnership processes and structures.

In order to negate conflicts of interest between partners, neutral facilitators can help balance the interests of different stakeholders and build on common ground between stakeholders. These facilitators must be trusted and endorsed by all parties. ${ }^{165}$

\section{Defining relationships}

When partnerships are being set up, partners should be required to determine what the roles of each partner will be and to create guidelines that ensure equality. This will ensure fair representation in decision-making and contribution to the partnership's efforts.

\section{F Further Guidelines and Structure within Partnership Framework}

While partnerships are a promising governance approach, their effectiveness cannot be assumed. Ivanova argues that without careful structuring and guidelines, they could be used to "perpetuate an illusion of progress" rather than attain tangible results. She cites internal structure as a key factor in determining the effectiveness of partnerships. ${ }^{166}$

The CSD-11 Guidelines provide loose criteria for WSSD partnerships. ${ }^{167}$ Yet this does not go far enough if partnerships are going to be considered a legitimate global environmental governance mechanism. The requirements for partnerships needs to be more comprehensive and specific to ensure the activities are of high quality and are in accordance with agreed sustainable development aims.

The formation of partnerships is currently completely ad hoc. They are uncoordinated and not driven by needs. Guidance is needed in suggesting areas where partnerships can be of most benefit.

164 Royal Institute of International Affairs, above n 94.

165 Royal Institute of International Affairs, above n 94.

166 Ivanova, above n $46,17$.

167 UN Commission on Sustainable Development "Report on the eleventh session", above n 14, outlined above at Part II A 4 CSD Guidelines for partnerships. 
There needs to be a balance in the issues covered by WSSD partnerships to ensure a fair sectoral and geographic representation, as mandated by the General Assembly. ${ }^{168}$

\section{Creation of further guidelines}

Partnerships need a set of official rules to allow adequate tracking of progress. ${ }^{169}$ These rules would need to address prerequisites for acceptance, power asymmetries, lack of accountability, monitoring and other pressing issues. However, it would still be important to maintain a degree of flexibility in how partnerships can be structured. Flexibility is one of the key strengths of partnerships. Therefore, guidelines could set requirements on important aspects such as accountability and monitoring, but not on the structure of partnerships.

\section{Establishing action plans}

It is important to strengthen the framework regulating each individual partnership. To retain flexibility, this should be done by each partnership individually. One way of achieving this is to require partnerships to establish action plans, which are registered with the overarching organisation. The Royal Institute of International Affairs recommended partnerships should bring together all the stakeholders to develop and implement action plans which: ${ }^{170}$

- $\quad$ have clear objectives;

- identify indicators against which to measure progress;

- identify the different actions of each partner;

- develop strategies to enable partners to work and achieve more than they could alone; and

- bring new resources.

\section{Clearer definition of aims}

Currently partnerships must aim to implement sustainable development agreements such as Agenda 21 and the Johannesburg Plan of Implementation. However, these documents are less than ideal guides. Agenda 21 is considered notoriously broad, covering too much terrain to be susceptible to oversight and planning. ${ }^{171}$ While much shorter, the Plan of Action essentially covers the same ground as Agenda 21. Though partnerships are decentralised and fragmented in nature, to

168 UNGA Resolution 129 (19 December 2003) A/RES/58/129.

169 Thorsten Benner and others "Moving the Partnership Agenda to the Next Stage: Key Challenges" in Witte, Streck and Benner, above n 12, 85-86.

170 Royal Institute of International Affairs, above n 94

171 Andonova and Levy, above n 25, 30 . 
be truly effective they need to be tied to the international sustainable development agenda. ${ }^{172}$ The WSSD partnership process should give clear guidance on where priorities lie for development and management of partnerships.

By having an international organisation responsible for identifying areas where partnerships are needed, these problems could be overcome. This organisation should channel partnerships into priority areas and provide coordination so that resources can be allocated in the most effective and efficient way. ${ }^{173}$

\section{G Greater Role for the CSD}

The CSD is the ideal body to take on many of these responsibilities. The CSD is currently the body charged with supervising partnership registration and creating guidelines. While currently the CSD has very little power, or influence and few resources, ${ }^{174}$ there is opportunity for it to build these up over time in relation to partnerships.

The CSD could facilitate partnerships that deal with the subject matter of environmental treaties and coordinate with treaty bodies to develop partnerships. The CSD could be responsible for monitoring. They would collect and analyse partnership reports, identifying those in need of follow-up. The CSD would also facilitate cluster groups and publicise successful and unsuccessful methods. While not necessarily having to source all the personnel and expertise internally, the CSD should be responsible for providing training and neutral facilitators. The current CSD guidelines can be supplemented by greater requirements on accountability, monitoring, relations between partners, establishing action plans and other issues.

This heightened responsibility may require that there is some reconfiguration of the CSD. It is likely to require additional funding. However, the WSSD partnership system would become the central facility for dealing with sustainable development implementation. This will give the CSD's activities greater priority within the UN system.

The United States is resistant to the possibility of giving the CSD or any other international institution a role in identifying potential gaps and facilitating new partnerships in those areas, as this could involve the CSD dictating to states what action should be taken. Instead they favoured having the CSD as merely a venue for discussing partnerships. ${ }^{175}$ However, the WSSD partnership process

172 Benner and others, above n 169,86 .

173 Benner and others, above n 169, 86 .

174 Birnie and Boyle, above n 21, 52.

175 "Type II Outcomes" (30 May 2002) Earth Negotiations Bulletin on the Side (International Institute for Sustainable Development and UNDP) 2. The members of the United States delegation made this assertion in a number of informal meetings. 
will be less effective without the institutional strength of an organisation to provide oversight, external accountability and guidance.

At the same time, it would be important to ensure that the CSD does not simply become an additional layer of bureaucracy, adding time and expense to the partnership process. Flexibility and creativity are important strengths of partnerships. In carrying out its additional responsibilities, the CSD would need to place great emphasis on deferring to regional and local strategies and programmes.

\section{CONCLUSIONS}

The World Summit on Sustainable Development in Johannesburg in 2002 introduced an innovative concept into the world of sustainable development governance. Birthed amid controversy and discontent at the lack of new agreements at the Summit, partnerships seek to draw multiple actors into programmes to achieve a huge variety of sustainable development outcomes. The WSSD Type II Partnerships currently operate within an underdeveloped and vague institutional structure.

The position of prominence given to partnerships at the Summit may seem surprising, yet the ineffectiveness of previous methods of achieving sustainable development and general political hostility towards further international obligations provide explanation. Partnerships are also a mechanism that is compatible with a complex international system with numerous actors.

The question of whether partnerships deserve the emphasis they have been given in sustainable development governance remains open. A number of concerns about the functioning of partnerships have been raised. Yet these difficulties are not insurmountable. Type II Partnerships can potentially deliver significant practical benefits to the implementation of sustainable development targets. If these strengths can be harnessed and the weaknesses minimised, then partnerships can indeed become a valuable tool in international environmental governance, and one which the international arena is justified in emphasising.

There are several theoretical and practical considerations that provide guidance on how partnerships can best be utilised. Development theory and practice indicates that a locally focused, participatory approach is necessary. The legitimacy of the process must be enhanced as much as possible. There is also a need to guard partnerships from potential problems arising from the participation of the private sector.

As a result of these considerations and the analysis of strengths and weaknesses, a series of principles has been formulated to guide improvements to partnerships:

(1) partnerships should promote and supplement international environmental law;

(2) partnerships must have high standards of transparency and accountability;

(3) partnerships need to take a participatory and locally oriented approach; 
(4) capacity of stakeholders needs to be built through learning and information sharing;

(5) the roles of partners and relationship between them within partnerships needs to be clarified and maintained; and

(6) the general partnership framework requires further guidelines and structure.

This article provides a number of strategies for improving partnerships. Most significantly, several ways for establishing a close relationship between Type II Partnerships and international agreements are suggested. Increasing the powers and responsibilities of the Commission for Sustainable Development is advocated as a way of coordinating partnerships across the globe and providing the structure and assistance that will enhance partnerships' effectiveness.

Type II Partnerships are a practical mechanism, which, in combination with international agreements, provides hope for making progress in achieving sustainable development. 
